\title{
Reality rhymes - recognition of rap in multicultural Norway
}

Toril Opsahl $^{\mathrm{a}}$ and Unn Røyneland ${ }^{\mathrm{b}}$

${ }^{\mathrm{a}}$ Toril Opsahl

University of Oslo

Department of Linguistics and Scandinavian Studies

Box 1102 Blindern

0317 Oslo

Norway

toril.opsahl@iln.uio.no

${ }^{\mathrm{b}}$ Unn Røyneland

University of Oslo

Center for Multilingualism in Society across the Lifespan, MultiLing

Box 1102 Blindern

0317 Oslo

Norway

unn.royneland@iln.uio.no

\begin{abstract}
In this paper we examine the role of Hip Hop and rap lyrics in the reevaluation and legitimisation of a new mulitethnolectal speech style developed in multiethnic and multilingual environments in Oslo, Norway. This speech style, commonly refered to as "Kebab-Norwegian", has been met with negative attitudes not only from the establishment but also in mainstream media. However, attitudes seem to be changing, partly due to the efforts of
\end{abstract}


rappers from immigrant backgrounds who promote themselves as users and propagators of the new speech style. They take a clear stance against the prevalent idea that "Kebab-Norwegian" poses a threat to the Norwegian language. In our paper we present on-going research on some of the most recent high school textbooks where lyrics from these performers have been included, and we also consider the strategies of promotion employed by some of the publishing houses.

Keywords: Hip Hop, multiethnolect, style, dialect, pedagogy, commodification

\section{Introduction}

\subsection{Framing and objectives}

Hip Hop clearly plays an important role in the lives of youth around the globe, connecting them in a supranational community of practice, and granting them a voice for expressing their local concerns and desires (Alim, 2009; Pennycook, 2007; Terkourafi, 2010). Hip Hop makes sense in many ways, by connecting the global and the local and providing tools for expressing both resistance and belonging (Cutler \& Røyneland, 2015). Recent work on language and identity among urban youth in multiethnic environments in Norway suggests that Hip Hop also plays a decisive role in the creation and formation of a new, multiethnolectal urban speech style (Brunstad, Røyneland \& Opsahl, 2010; Cutler \& Røyneland, 2015). By 'multiethnolectal speech styles' we mean particular speech styles that are characterized by the inclusion of linguistic features from many different varieties, used by people with several ethnic backgrounds, to express their minority status and/or as a reaction to that status to upgrade it (e.g. Clyne, 2000; Eckert, 2008; Quist, 2008; Svendsen \& Røyneland, 2008). Among the self-proclaimed users of such a speech style in Norway, the vast majority express affiliation to the four classic elements from Hip Hop culture, through a preference for rap 
music, Dj-ing, graffiti, break dancing, and/or through a particular clothing style often associated with Hip Hop, or several of these elements.

In our article we argue that there is an emerging change in attitudes toward this multiethnolectal speech style, which potentially contributes to a new understanding of the overall dialect situation in Norway. These attitudinal changes are, we claim, partly a response to the efforts of Hip Hop artists, especially rappers. Dialects and to some degree sociolects have high idelogical value among Norwegians (e.g. Røyneland, 2009; 2010). Dialects are generally widely accepted and used both within private and public domains - also within different musical genres like Hip Hop. ${ }^{1}$ After an initial phase where English was the dominant language, Norwegian rap went through a period of "Norwegianisation" and today many rappers use their local dialects, however often with American English Hip Hop expressions interspersed as a way to reference the provenance of African American Hip Hop (Brunstad, Opsahl and Røyneland 2010). Authenticity in Hip Hop is to a large extent determined at the local level. Local languages — both indigenous and migrant—as well as local dialects have become the 'base languages' of local Hip Hop scenes as well a key marker of local authenticity (Androutsopoulos 2009; Terkourafi 2010). "Keepin it real", thus, both entails keepin it local, or street, by capitalizing on different aspects of localness and keepin it global by displaying loyalty to the culture of the hip-hop genre (Terkourafi 2010).

We are not studying Hip Hop as pedagogy, but rather more indirectly how Hip Hop has consequences for pedagogy, in the sense that it has contributed to the reevaluation and legitimisation of "Kebab-Norwegian", which has in turn has fed into pedagogical resources

\footnotetext{
${ }^{1}$ Dialects are here understood in the traditional sense-i.e. as geographically defined varieties-whereas sociolects are understood as a set of features that are typical for certain social groups (e.g. Chambers \& Trudgill, 1980). Notwithstanding, it may be rather tricky to keep dialects, sociolects and ethnolects apart as they may get conflated, particularly in urban areas; people who reside in a specific geograpical area often belong to the same social group and sometimes also the same ethnic group.
} 
and into other mainstream, middle-class cultural manifestations. Hip Hop practices interact with dominant language ideologies both inside and outside educational contexts. We examine a selection of high school textbooks adhering to the revised Norwegian national curriculum standards from 2013, to show how Hip Hop elements interact with representations of linguistic diversity in Norway. Through a content analysis, we consider where and how the textbooks thematise the new, multiethnolectal speech style, and whether reference to Hip Hop is made. Further, we offer some examples of the impact that Hip Hop artists' emblematic performances have had in the media, and especially on the general public. The interplay between identity formation by which young people conceive themselves and others, several Hip Hop elements, and textbook producers' interpretations of the national curriculum standards may be contributing to a new understanding of linguistic diversity. This in turn may lead to a less puristic and normatively more flexible spoken language ideology.

On a more general level we ask how Hip Hop practices interact with dominant (standard) language and literacy ideologies, and how various conceptions of language and society are bridged and transformed in educational settings in a society sometimes refered to as a "dialect paradise". Trudgill emphasizes that there is great societal tolerance for linguistic diversity in Norway "[...] and that, what is more, linguistic diversity in Norway is officially recognised and protected" (Trudgill, 2002, p. 31). In fact the Norwegian Parliament decided in 1878 that no particular spoken standard should be taught in elementary and secondary schools. This principle is still valid today and has no doubt been essential for the continued use of local dialects in Norway and for the contentious position of the oral standards (e.g. Jahr \& Mæhlum 2009). An interesting question is whether this tolerance for diversity applies to all kinds of linguistic variation. We explore some parallels between historical language struggle and debates and the creation and formation of a new, multiethnolectal urban speech style, and we 
suggest that this parallelism provides some interesting implications for the pedagogic practices in classrooms.

The Norwegian case may in turn contribute to the wider debate about emerging translinguistic varieties in urban contexts, along the lines, e.g., of the metrolingualism proposed by Pennycook and Otsuji (2015) and ideological debates regarding the concept of purism. Moreover, our case study suggests that the commodification of language is a complex, multilayered phenomenon (Cutler \& Røyneland, 2015; Heller, 2010; Duchêne \& Heller, 2012). Hence, a commodity is any (linguistic) semiotic resource which may be traded into other, more valuable resources, such as for instance increased social status or higher income. Hip Hop artists use multiethnolectal features as a commodity in their self-promotion. At the same time, Hip Hop elements seem to be used as a commodity by publishers in the promotion of the new high school textbooks. This double aspect of commodification brings into view the question regarding the schools' and educators' perceptions and legitimisation of Hip Hop as culture.

\subsection{Sociolinguistic speech style}

The new speech practices found in contemporary multilingual urban areas may, in our view, best be descibed as a multiethnolectal speech style. We prefer to use the term style and not variety, since a sociolinguistic style includes a wider range of semiotic symbols than a variety, which is restricted to linguistic items alone. Style may be defined as a clustering of resources, including linguistic resources, and an association of that clustering with social meaning and with an identifiable aspect of social practice (cf. Eckert, 2001, p. 123; Quist 2005, p. 76). Whereas the study of varieties is basically structuralist in its approach to variation, the study of styles sees variation as a resource for self-positioning in social space, and is more 
concentrated on how social meaning is created through language. Social style is, according to Auer (2007), a multilevel phenomenon which directly challenges, and which may overcome, the more traditional approach to linguistic variation where focus often lies on single variables.

\subsection{Linguistic characteristics of and attitudes towards multiethnolectal Norwegian}

The multiethnolectal speech style is characterized by a vide range of co-occurring linguistic features including an association of these features with certain social practices. A closer look at the specific linguistic phenomena reveals at least three patterns of development (Ekberg, Opsahl \& Wiese, 2015): Contact-induced changes, such as lexical loans from some of the background languages available in the communities; new patterns that arise from an extension of lexical material or grammatical patterns offered by the respective majority languages; and, finally, developments that reflect phenomena of general language change, such as the interaction of weaker grammatical constraints and a more direct realisation of informationstructural preferences. A typical feature of multiethnolectal speech styles is an extensive and also extended use of loan words from immigrant languages. Some such words come to play the role of discourse markers with specific discourse functions (e.g. wallah $=$ I swear by Allah (Arabic)). Many are swear words or expressions that in other ways index cultural taboos or proscriptions (e.g. $k c e b e=$ prostitute/girl (Berber), maricon $=$ homosexual $($ Spanish), toesje $=$ steal (Berber) kotha/kohti=male/female dog (Punjabi)). Other common features of the speech style are violations of the syntactic V2 contraint, rendering a XSV word order, where ' $\mathrm{X}$ ' is a topicalised element, 'S' the subject and ' $\mathrm{V}$ ' the finite verb (e.g. *Plutselig han kom XSV 'Suddenly he came' instead of standard verb second Plutselig kom han XVS 'Suddenly came he'), as well as some morphological developments (e.g. grammatical gender simplification like the use of masculine gender with neuter nouns), some prosodic features (e.g. "staccato" sounding intonation), and the development of new determiners (for more examples from the 
Norwegian context, see Opsahl, 2009; Svendsen \& Røyneland, 2008). Several of these features are found in urban multiethnolectal speech styles across Scandinavia and also in other parts of Europe (see Nortier \& Svendsen (eds.), 2015, Quist \& Svendsen (eds.), 2010).

Analyses of how this linguistic development is covered in the media (Ims, 2014; Svendsen \& Marzo, 2015) and in a large internetbased survey (Ims, 2013) reveal large amounts of negative attitudes towards this speech style, and highlight the fact that we indeed are dealing with ideological struggles (which is nothing unique: see for instance Androutsopoulos (2010) for related cases in Germany). It is often argued that the use of this speech style is a hindrance for young people who are trying to enter the job market. In the media it is commonly referred to as "Kebab-Norwegian" and framed as something problematic (Svendsen, 2014). However, several Oslo-based rappers from immigrant backgrounds promote themselves as users of this new speech style and take a clear stance against the prevalent idea that it poses a threat to the Norwegian language. Two prominent rappers of immigrant background, Emire and Lillebror, stated in an interview some years back that:

It is really important not to believe that it is a language that is used when people don't know how to speak Norwegian, but on the contrary, it is an intelligent language that may help people to explain themselves better in the new Norwegian society (Aftenposten 23.10 .2007$)^{2}$

The new Norwegian society that Emire and Lillebror refer to is increasingly culturally and etnically mixed due to the labour- and refugee-driven immigration of recent years, contributing to an increased multilingualism.

\footnotetext{
${ }^{2}$ Det er veldig viktig å ikke tro at det er et språk som brukes når folk ikke kan snakke norsk, men tvert imot, det er et intelligent språk, som kan hjelpe folk til å forklare seg i Norges nye samfunn. (Aftenposten 23.10.2007)
} 


\subsection{Multilingual Norway}

According to Statistics Norway, 15.6 percent of the Norwegian population of 5.1 million inhabitants have immigrant backgrounds. Since most of them settle in and around the capital, numbers are higher there. Approximately 33 percent of the population in Oslo are foreignborn or Norwegian-born with two foreign-born parents (Statistics Norway, 2016). The largest immigrant groups today are job seekers from Poland and Sweden. The first labour immigrants were, however, from Pakistan. They may be considered the "oldest" immigrant group and their children are now the largest Norwegian-born group with two foreign-born parents (or "second generation immigrants"). Almost all of them live in the Oslo region.

Like many cities, Norway's capital, Oslo, is a socially and economically divided city. The river that runs through the city divides the East from the West. Traditionally the areas at the eastern side of river used to be a working class, industrial area, whereas the geographical region at the western side of the river was where the upper and middle classes resided. Although there is an on-going process of gentrification of the eastern area, we find more or less the same division today (e.g. Stjernholm 2013). Most of the immigrants living in Oslo reside in the eastern parts of the city. In some areas up to 80-90 percent of the school children have immigrant backgrounds. This dimension has affected the (socio)linguistic landscape of the city: Some of the traditional dialect differences between East and West seem to be converging, but a reinforcement of the East-West-opposition is visible in the emergence and use of features connected to the multiethnolectal speech style (e.g. Opsahl \& Røyneland 2009; Hårstad \& Opsahl 2013).

According to the curriculum for Norwegian language and literature, high school students ought, among other things, to acquire knowledge about dialect variation and change in present 
day Norway. Further, they ought to be able to account for Norwegian language debate and language policy from the 1800 s to the present day, and to give examples of multilingualism and discuss benefits and challenges of multilingual societies (Udir, 2015). Norway is itself an example of a multilingual society, with its long history of language contact between Norwegian and minority languages such as Sami and Kven in the northern territory, as well as migration patterns over the last four decades, introducing a multitude of new immigrant languages to Norway. According to the Language Council of Norway (2016), more than 150 minority languages are represented in Norway. In the capital, Oslo, 40, $2 \%$ of the pupils have a mother tongue different from Norwegian or Sami (Oslo Municipality, 2016).

In the next section we will demonstrate that many of the most recent textbooks have included a discussion of new, multiethnolectal urban speech styles as part of one or more of the chapters where linguistic diversity is discussed. As we will see, these discussions are often accompanied by examples from ethnically mixed Hip Hop groups who promote themselves as users and creators of this speech style. Propagated by rappers like Emire and Lillebror, who described a "new Norwegian society" above, new ways of speaking are in fact introduced into the dialect flora of Norway and are potentially influencing pedagogical practices through their inclusion in textbooks.

\section{Hip Hop and linguistic diversity}

\subsection{Kebab Norwegian in high school textbooks}

Dadi Jr., a prominent member of the rap collective called Minioritet1 ('Minority 1') ${ }^{3}$, names, discusses, and demonstrates the multiethnolectal speech style of eastern Oslo in the following

\footnotetext{
${ }^{3}$ The name Minoritet 1 plays on two possible understandings. It may be perceived both as "minority number one" and as "the minority", as the pronunciation of 1 and the definite singular particle -en is identical in Norwegian ('minoriteten' - definite form singular). Clearly the members of this Hip Hop collective position themselves as representatives of minorities in Norway-voicing their social struggles and concerns in a voice of
} 
excerpt, which is included in the dialect chapter in a brand new high school textbook (Furumo et al., 2015, see Table 1). ${ }^{4}$ The starting point—and the pivot point—is geography: The divided city. This division is intertwined with social issues, and Dadi Jr. contrasts the multiethnolectal speech style both with the Western, high prestige, Oslo dialect and with Norwegian L2 in his rap. Cutler and Røyneland (2015) show how Dadi Jr., through stylized performances of the latter two, juxtaposes both of these with the urban multiethnolectal repertoire. He concludes the rap by domesticating and neutralizing this speech style, which he interestingly labels “Kebabnorsk” ('Kebab Norwegian'), a label often perceived as negative and stigmatizing by the users of this speech repertoire (e.g. Aarsæther, 2010; Kulbrandstad, 2004; see Ims, 2013 for a discussion). ${ }^{5}$

\section{Excerpt (1)}

\section{Dadi Jr. Frå Minoritet 1 og Mørk Atmosfere: Kebabnorsk}

1. Tror du det vi snakker er så uvanlig?

2. Om du er fra Vestkanten eller fra drabantbyen

3. kebabnorsk, du vet sånn gatespråk

4. kebabnorsk, yo det snakkes i min blokk

5. kebabnorsk, for svarte og hvite folk

6. kebabnorsk, som om du blander, kebab med torsk

7. kebabnorsk, «hva ser do på vil do ha bråk» [stilisert L2]

8. kebabnorsk, en blanding av smått og flott

9. kebabnorsk, vi hakker bare orda opp som en kebabkokk, yo, kebabnorsk

their own. The group consists of young people from many different backgrounds including Norwegian ethnic background.

${ }^{4}$ Other Oslo-based rappers from immigrant backgrounds apart from Minoritet 1 and Dadi Jr., who also make use of and claim a strong ownership of features from a Norwegian multiethnolectal repertoire, are artists such as Danny Maroc, Pumba, Emire, Lillebror (Assad), Haji, Amina, (Forente Minoriteter) and Karpe Diem.

${ }^{5}$ As pointed to by Ims (2013) the label 'Kebab Norwegian' has undergone a re-evaluation and it is today considered "neutral" by many. The "Cultural School bag" mentioned in section 2.4 below used for instance "Kebab Norwegian" in their promotion of the theatre production Romeo and Juliet in Rap. 
Dadi Jr. From Minoritet1 and Dark Atmosphere: Kebab Norwegian

1. Do you think what we talk is so unusual?

2. If you're from the west side or from the suburbs

3. Kebab Norwegian, you know like street language

4. Kebab Norwegian, yo, it's spoken on my block

5. Kebab Norwegian, for Black and White folk

6. Kebab Norwegian, as if you mix kebab with cod

7. KebabNorwegian, "what are you looking at do you want trouble?" [stylized L2]

8. Kebab Norwegian, a mixture of small and great

9. Kebab Norwegian, we only chop up the words like a kebab chef, yo, Kebab Norwegian

In these lyrics, Dadi Jr. is evidently claiming a place for himself and his language. In this practice there is also an inherent connection, both historically and as part of an everyday linguistic practice, to the local, geographical area. In this respect, Dadi Jr. is clearly adhering to the existing positive attitudes towards dialectal variation among Norwegians (NRK/Norstat 2014; Røyneland, in press). This excerpt is probably the most striking example of how Hip Hop elements interact with and transform traditional notions of linguistic diversity and belonging to a place in our corpus, but there are others. The connection between language, belonging and place, in a traditional dialect-geographical sense, is prominent in the rap lyrics and the textbook authors' and publishers' framing of Hip Hop elements. We have examined textbooks from the best-known publishers in our analysis, all possesing a relatively strong foothold in the publishing market in Norway. The rationale for selecting these publishers' books is the fact that they have been market leaders, and that they all were financially solid enough quickly to produce new textbooks as a response to the revised national curriculum in 2013. We are focusing on textbooks covering the high school curriculum where the students 
are required to learn about dialect variation according to the national curriculum standard. We carry out a traditional discourse analysis focusing on all semiotic resources (text, photographs, illustrations, fonts, etc.), and consider where and how the textbooks thematise the new, multiethnolectal speech style, and whether parallel reference to Hip Hop is made. The analysis is not comprehensive, but we have included all the largest publishers' new textbooks adhering to the 2013 reform, and the elements we find and highlight in the textbook corpus will, hopefully, serve as necessary illustrations to our claim about traces of a new dialectal orientation.

Table 1: Textbooks - an overview

\begin{tabular}{|c|c|c|c|}
\hline Publisher: & Fagbokforlaget & Aschehoug & Gyldendal \\
\hline General $^{6}$ & $\begin{array}{l}\text { Kvåle Garthus et al. (2013): } \\
\text { Intertekst } 1 \\
\text { Eide et al. (2015): Intertekst } 3\end{array}$ & $\begin{array}{l}\text { Dahl et al. (2013): Grip teksten } 1 \\
\text { Dahl et al. (2015): Grip teksten } 3\end{array}$ & $\begin{array}{l}\text { Røskeland et al. (2013): } \\
\text { Panorama } 1 \\
\text { Røskeland et al. (2015): } \\
\text { Panorama } 3\end{array}$ \\
\hline Vocational & $\begin{array}{l}\text { Andresen et al. (2014): } \\
\text { Signatur } 2 \\
\text { Andresen et al. (2013): } \\
\text { Signatur } 3\end{array}$ & $\begin{array}{l}\text { Gitmark et al. (2013): Norsk for } \\
\text { yrkesfag } 1 \\
\text { Furumo et al (2015): Norsk for } \\
\text { påbygging } 3 \text { (extension) }\end{array}$ & $\begin{array}{l}\text { Gedde-Dahl et al. (2013): } \\
\text { Tett på } 1 \text { and } 2 \\
\text { Gedde-Dahl et al. (2016): } \\
\text { Tett på (extension) }\end{array}$ \\
\hline
\end{tabular}

These pedagogical works discuss the linguistic practices of current rap music in an engaging, non-dismissive manner, and juxtapose rap lyrics with dialects and sociolects, which have a high ideological value among Norwegians.

\subsection{Traces of a new ideological orientation?}

All the twelve new textbooks in our corpus discuss "Kebab Norwegian" as part of their chapters on linguistic variation, dialects, sociolects and history of language, and, as many as

\footnotetext{
${ }^{6}$ All adolescents have a legal right to attend high school in Norway, and most of them do. They may choose between a general (academic) and a vocational program.
} 
nine of them connect emergent multiethnolectal speech styles to Hip Hop, either through the visual framing of the content and/or through the inclusion of rap lyrics. The fact that there is a certain potential value in focusing on emergent multiethnolectal speech styles and Hip Hop is quite evident. One of the textbooks launched in 2015 (Furumo et al., 2015) has already been analysed for including Dadi Jr.'s text "Kebab Norwegian". The authors of that textbook have also included a picture of the two above-mentioned rappers Emire and Lillebror with the caption "Emire and Lillebror rap in 'the new Norwegian'." (Furumo et al., 2015, p. 241). The same publishing house, Aschehoug, has also included rap lyrics to illustrate 'the new Norwegian' in their textbook aimed at first year high school students (Gitmark et al. 2013, p. 226). Here a picture of a young Norwegian rapper of Morrocan-Norwegian decent, Danny Maroc, and the entire lyrics of his rap Norsk 2 ('Norwegian 2') is included. In his rap Danny addresses several issues regarding the multiethnolectal urban speech style. He talks about how it was created (by mixing up the grammar and playing around with it), who created it (people of mixed origin), why and with what objectives it was created (to include and to avoid cultural clash', but also to exclude others). He also names the multiethnolectal urban speech style (Norsk 2) and he takes a clear stance against people who believe that Norsk 2 corrupts the Norwegian language. A short example from the hook may illustrate this:

\section{Excerpt 2}

\section{Norsk 2}

Språket ble etablert her

Norsk 2

For å unngå kulturkræsj

Norsk 2

Et lite stykke Norge

Norsk 2 
Det er bare sånn det er

\section{Norwegian 2}

The language was established here

Norwegian 2

To avoid cultural clash

Norwegian 2

A little piece of Norway

Norwegian 2

That's just how it is

As discussed by Cutler and Røyneland (2015, p. 156), the phrase 'a little piece of Norway', refers to an advertisement, very well known to all Norwegians, for the iconically Norwegian chocolate bar, Melkesjokolade ('Milk Chocolate'). Danny is making the point that he and people like him from immigrant backgrounds and their distinctive way of speaking are also a part of Norwegian society - they constitute, in effect, 'a little piece of Norway'. The label itself, "Norsk 2", also indexes national belonging and legitimacy in Norway. This is an illustrative and powerful example of language and national/local identity making through Hip Hop lyrics.

The textbooks Intertekst 1 (Kvåle Garthus et al. 2013), Intertekst 3 (Eide et al., 2015), Grip teksten 3 (Dahl et al., 2015), and Tett på 1 \& 2 (Gedde-Dahl 2013) also include illustrations of Hip Hop elements, rappers on stage and/or graffiti, in their chapters on spoken language. Grip teksten 1 (Dahl et al., 2013) include such elements in a section with texts illustrating 'cultural encounters'. Intertekst 3 include several rap lyrics, both in the theory book and the additional textbook. An entire page is devoted to an analysis of the rap text Vestkantsvartinga ("West 
End Niggers") by Karpe Diem, and guest rapper Pumba (the exact same text is also used in Tett på 1 \& 2). These lyrics point-as Dadi Jr.'s lyrics did-to a description of the geographical and social lines of separation in the capital, and the close ties between geography, social belonging and identity. Even though the divided city is underlined in the lyrics through exaggerated description of ethnic dimensions (ex. A), there is a sense of unity in the hook of the rap, where the city is seen as "my city" (ex. B): .

\section{Excerpt 3}

A) Der borte er du unik, det er i hvert fall kult dét, da

Her er jeg én svarting av femten-tusen-og-én, ass

'Over there (i.e. at the West end), you are unique, at least that's cool

Over here (i.e. at the East side) I am one blackie among fifteen thousand and one, you know'

B) Hvor eru bor hen a?

Eyh la meg ta deg med til byen min, b-byen min, b-b

Hvor eru bor hen a?

Eyh la meg ta deg med til ah.. ta-ta deg med til Oslo

\footnotetext{
'Where do you live, ey?

Ey, let me take you to my city, my city.

Where do you live?

Ey, let me take you to, take you to Oslo.'
}

The visual framing of the discussions of linguistic diversity is also quite striking in the Signatur 3 textbook (Andresen et al., 2013). The book includes a full page illustration of a boy breakdancing in front of a fish shop in Northern Norway. <illustration> 


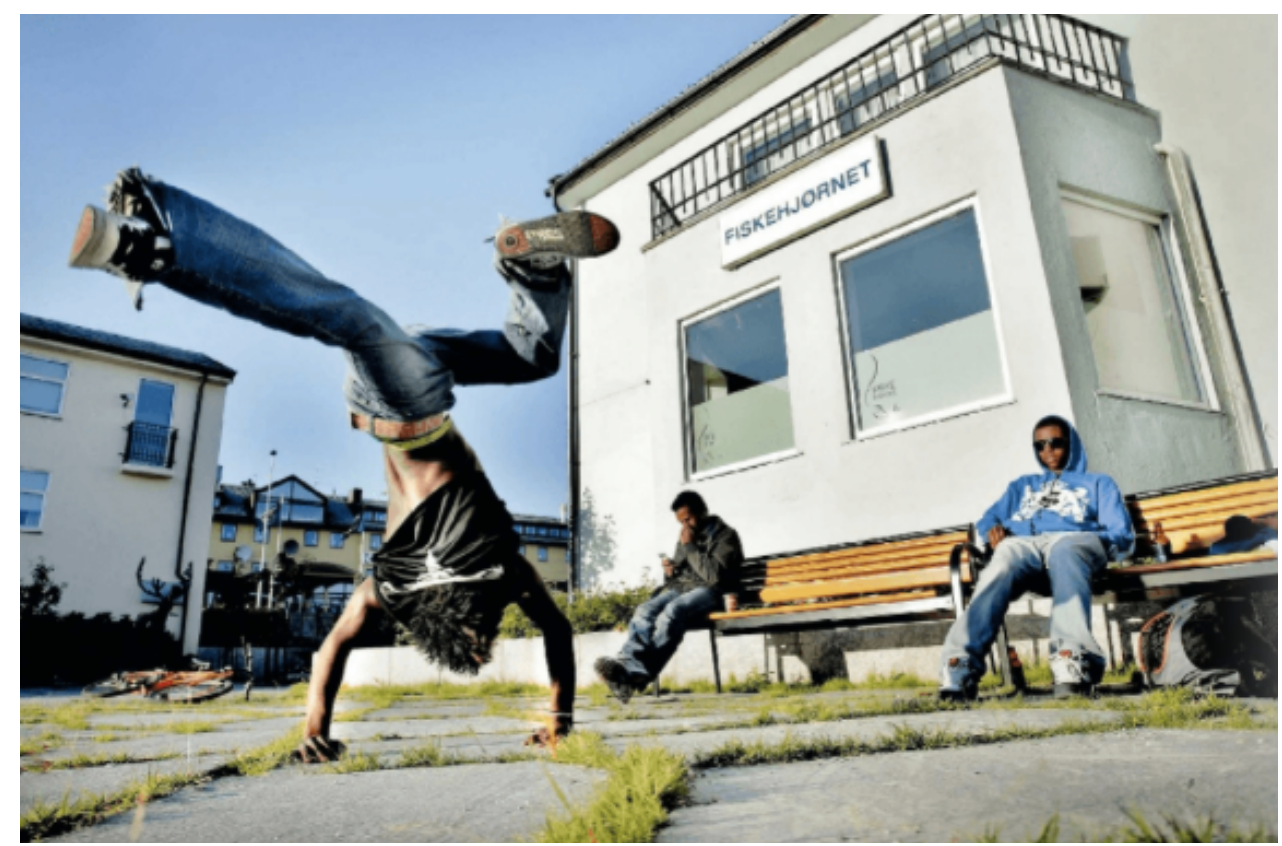

From Signatur 3 (Andresen et al., 2013, p. 102). The sign on the wall says "The fish corner",

Photo: Øyvind Nordahl Næss/NTB scanpix

This juxtaposition of elements is especially interesting in its ability-in a rather subtle wayto evoke and challenge several traditional assessment dimensions which are relevant in the Norwegian context, such as urban-rural, standard-dialect, high status-low status. Historically the dialects in the north of Norway have suffered heavily from disparagement, and people from the north of Norway moving to the capital, Oslo, were met with skepticism and even racism on the housing and employment market. Many of the Northern varieties are characterized by traces of extensive language contact between North Germanic, Finno-Ugric and Slavic languages (Sollid 2009; 2014). The northern varieties challenge the purist ideals, and thus "did not fit into the ideology of the dialect research", as Sollid (2014, p. 112) puts it. In some cases Northern varieties were virtually erased from the dialect landscape. They were scarcely described and often not included in the traditional dialect maps. Today, however, the evaluations associated with the rural or geographically periphery and new urban speech styles are turned upside down (Ims, 2014). In the high school textbooks, as illustrated from the 
Signatur 3 textbook's textual and visual content, both dialects from NorthernNorway, multiethnolectal speech styles and breakdancing form part of the the school curriculum concerning dialects and linguistic variation, thus contributing to normalizing linguistic and artistic diversity.

\subsection{Preliminary discussion}

The textbooks' juxtaposition of the linguistic practices of rap lyrics with dialects and sociolects implies that the multiethnolectal speech style is framed as being a part of the Norwegian sociolinguistic history and landscape, or, more precisely, the Norwegian dialect landscape. We have seen how the enregisterment of the multiethnolectal speech style has parallels both in present and historical language struggles in Norway, as the case of Northern Norwegian language diversity demonstrates. Where overt struggle may appear to have subsided, potential conflict is ever lurking in the shadows, though, especially when we turn to the question of written Norwegian. Since 1885, two written standards, Bokmål and Nynorsk, have coexisted as legally equal, juxtaposed written representations of Norwegian, which all Norwegian pupils are required to learn. Notwithstanding, Nynorsk has since the very beginning had a minority status - both in terms of users, power and prestige. In short, the Bokmål standard was based on the Dano-Norwegian varieties spoken by the urban elites, whereas the Nynorsk standard can be traced back to Ivar Aasen's (1813-1896) compilations of rural dialects in the late $19^{\text {th }}$ century (for comprehensive historical accounts and discussions of recent developments see Haugen 1966; Jahr 2003; Røyneland 2013). Nynorsk is today used only by a minority of the Norwegian population (approximately $13 \%$ ), and expressions of negative attitudes towards the minority standard Nynorsk are quite common (e.g. Grepstad 2015; Thingnes, 2015). The opposition between Nynorsk and Bokmål is linked both to geographical (Western Norway versus the rest of the country) and social (rural versus urban) 
oppositions. The history behind the Norwegian written language situation has a quite prominent place in the school curriculum. In Oslo, like in all the major cities of Norway, Bokmål is the dominating standard. The rap lyrics presented in the different textbooks above, are without exeption written in Bokmål, but with many deviation from standard orthography and inclusion of multiethnolectal features.

There appears to be quite a strong awareness among Norwegians of the fact that there is nothing neutral about the choice of a written standard, or the choice between variants within the standards. People are well aware of the sociolinguistic indexicality of different variants, and may vary their orthography depending on aim and context. In computer mediated communication many people even use their dialect in informal writing (SMS, chatting, facebook etc.) (e.g. Rotevatn 2015). Ims (2014) reveals how the media contributes to processes whereby different registers are attributed values along traditional assessment dimensions such as urban-rural, standard-dialect and high status versus low status, but also that these traditional polarities now have acquired an ethnic dimension (see also Opsahl \& Røyneland, 2009). There is a geographical, cultural and/or political meaning potential attached to the available choices. This awareness is also present when it comes to oral varieties, and there are, we claim, strong parallels and links between "new" ideological enregisterment processes and historical Norwegian language debates, all reflected in the school curriculum. From these perspectives, the multiethnolectal speech style-with its connections to Hip Hop culture-have clear didactic implications in its ability to highlight past and ongoing sociolinguistic processes expressed in the national curriculum. The historical parallels may be one of the reasons why we also witness a possible change in the overall understanding of present day socio-geographical variation in Norway where the multiethnolectal speech style - in some contexts - is promoted and perceived as a dialect. In 
fact several of the textbooks in our corpus explicitly frame multiethnolectal Norwegian as a new dialect: "A new variety called multiethnolect has emerged. This term is used about a new Norwegian dialect with elements of slang from several different foreign languages"7 (Andresen et al., 2013, p. 96, our italics). One argument for calling this [i.e. the multiethnolect] a dialect is that this spoken language belongs to the Eastside of Oslo" (Kvåle Garthus et al 2013, p. 270, our italics).

Mixed or levelled ways of speaking, as opposed to traditional, 'authentic' dialects, have traditionally been held in contempt by many Norwegians (e.g. Mæhlum \& Røyneland, 2009). The paradox herein is that the mixing and combination of elements is what in fact constitutes the multiethnolectal speech style. Emerging attitudinal changes are evident, we claim, from the fact that rap lyrics from performers using multiethnolectal speech styles have been included in the high school textbooks. At the same time, Hip Hop culture and multiethnolectal speech styles are bearers of a potential oppositional value, a point we will return to in section 3.1. It is interesting, though, to look for parallels to these oppositional practices in Norwegian language history, especially with regard to the minority written standard, Nynorsk, which is based on a broad variety of Norwegian dialects. It is also tempting to point to the fact that both Nynorsk and multiethnolectal speech styles have been created and have emerged as a fusion of elements from and/or a common denominator for multiple varieties, though this point may actually exaggerate the impression of similarity between the cases.

The fusion of elements from various cultural impulses provides an opportunity to embrace the diversity of both one's local community and the global Hip Hop community of which one is a part. The same role as a bridge may be filled by the use of a multiethnolectal speech style.

\footnotetext{
${ }^{7}$ Der [i de større norsk byene] har det oppstått en annen type talemålsvariant som kalles multietnolekt. Dette begrepet brukes om en norsk dialekt med innslag av slang fra flere fremmede språk.

${ }^{8}$ Eit argument for å kalle det [multietnolekten] ein dialekt er at dette talemålet høyrer heime i Oslo aust.
} 
This is probably one of the reasons why we find so many and clear cases of the combination of multiethnolectal speech styles and Hip Hop cultural elements. By virtue of their position in the youth communities, urban Hip Hop performers seem to have significant influence on both the formation and the propagation of linguistic innovations.

\subsection{Kebab Norwegian on different arenas}

Rap culture featuring in mainstream middle class culture seems in particular to contribute to normalizing these linguistic and artistic innovations. That is to say, including these cultural artifacts in traditional forms of expressions, such as novels and classical theatre, seemingly reevaluates and legitimizes these otherwise "underground" language practices. Some years ago, Emire and Lillebror, whom we met earlier, rendered William Shakespeare's Romeo and Juliet in "Kebab Norwegian", situating it in a modern, urban environment. First staged at a small, alternative theatre in Oslo (2007), the play was eventually a success at the Oslo Concert Hall (2010), and at the prestigious Bergen Music Festival (2011). In addition the play was offered to a number of Norwegian upper secondary schools and high schools in the Oslo area, as a part of "The Cultural Schoolbag" (a national initiative and collaboration between the Ministry of Science and the Ministry of Culture).

Another example of the use of "Kebab Norwegian" in mainstream culture, is the literary debut of the young writer Maria Navarro Skaranger (2015). Her novel on an ethnically mixed suburb of Oslo, had an overwhelming reception and was framed as the first novel written in “Kebab -Norwegian”. One critic writes:

Young people in literature often represent new times. Sometimes it also happens in a new language. [The debut] describes the present day melting pot in a funny and up-to-date suburban 
dialect. Here is everything needed to ensure that linguists can have a great time: slang, anglicism, consistently wrong word order and Arabic loanwords from the childhood of KebabNorwegian. More conservative forces risk getting their red pencil overheated (Dagens Nceringsliv 23.01.2015). ${ }^{9}$

Interestingly, the speech style in question is described here as a "new language" and as a "dialect," and not as accented Norwegian, broken or corrupted Norwegian, or any other of various more or less derogatory labels that are frequently applied to mixed varieties such as “Kebab Norwegian” (e.g. Aarsæther, 2010; Blommaert \& Verschueren 1998; Ims 2013; Kulbrandstad 2004; Thomas 1991). This critic is, on the contrary, overtly positive and clearly fascinated by the book's language. The critic refers to the "childhood" or initial phases of "Kebab Norwegian", and describes some of its most stereotypical features (Arabic loan words). By referring to the book's language as a "new language" and as an "up-to-date suburban dialect", and not as "Kebab Norwegian", an impression of the speech repertoire as something more developed is created. It has become a geographically marked variety-a dialect. It is worth noting that two of the textbooks presented above, have included excerpts from Skaranger's novel as examples of "Kebab Norwegian” (Intertekst 3 and Panorama 3).

Signs of transformation from "alternative" to "mainstream" stages support the assumption that multiethnolectal stylistic expressions are assigned a more neutral status in general public awareness. They are perceived as elements of a repertoire that are becoming less stigmatized and more continuous with other, more traditional linguistic and cultural forms of expression. This is in many ways a classic example of how linguistic features may be subject to reevaluations when they are introduced to new linguistic markets, like the literary or artistic

\footnotetext{
${ }^{9}$ Det unge mennesket i litteraturen representerer gjerne nye tider. Av og til skjer det også på et nytt språk. [Debutboken] beskriver dagens smeltedigel på en morsom og oppdatert drabantbydialekt. Her ligger alt til rette for at språkforskere kan storkose seg med slang, anglisismer, konsekvent gal ordstilling og arabiske lånord fra kebabnorskens barndom. Mer konservative krefter risikerer å få rødblyanten ut av ledd. (Dagens Nceringsliv 23.01.2015).
} 
arena, in the Bourdieusian sense (Bourdieu, 1977; 1992). In the next section we will discuss our findings in light of language as commodity.

\section{Commodification of speech repertoires?}

\subsection{Oppositional versus mainstream}

The acceptance of multiethnic speech styles as legitimate and even valuable in new markets, attributed by inclusion in mainstream modes of expression - as well as the inclusion in the school curricula - is only part of the story. Youth from immigrant backgrounds as well as native-born youth in Oslo are also drawn to Hip Hop precisely for its oppositional symbolism. These young people will often deliberately aim to use language in ways that challenge hegemonic language ideologies (Cutler \& Røyneland, 2015). However, the form of such challenges will depend on local, contextually variable features. For instance — and in contrast to the situation we have described-Stæhr and Madsen (2014) show how hegemonic language-ideological beliefs that link linguistic standard and correctness to intelligence influence the linguistic practice in a group of young rappers in Copenhagen, Denmark, toward conformity with the dominant standard. In this case, the dominance of standard-linguistic practices is also related to audience considerations and the youngsters' ambitions of success as musicians. As Stæhr and Madsen (2014, p. 24) state in their conclusion: "Linguistically the local rap community is not counter-hegemonic, and rather than bringing linguistic indexes of minority status and youth culture to the front stage, the young rappers assimilate to linguistic majority terms, in the name of success and intelligence." This illustrates very effectively the need to "to take into account the local, socio-cultural meanings given to particular linguistic resources" (Stæhr \& Madsen, 2014, p. 1), especially since the situation seems to be rather different in Norway. 
In Norway, on the contrary, the rappers seem to benefit from bringing linguistic indexes of multiethnic youth culture to the forefront in their attempt to succeed as artists. Several of the Oslo-based rappers from immigrant backgrounds pitch themselves as inventers and users of the new, Norwegian speech style and use this actively as a means of differentiating themselves from other Norwegian rappers, and as a commodity in the promotion of their music (Cutler \& Røyneland, 2015). Drawing on theories of pride and profit (e.g. Duchêne \& Heller, 2012), one may say that the young rap artists are commodifying their pride as a minority in order to make a profit through their rap music. This may be the result of the different sociolinguistic climates, where Norway, as discussed in the introduction, traditionally has had great tolerance for linguistic diversity.

It is interesting to see how not only the rappers themselves, but also the publishing houses, capitalize on this new speech style, and hence how it is treated as a commodity to serve various ends. Given the great financial significance of high school textbooks for the publishing houses, the promotion of these works is a high-stakes activity, and is the result of careful, deliberate strategic planning. Thus, the striking use of Hip Hop elements and multiethnolectal features in textbook promotion is particularly revealing of their commodity value.

Aschehoug, one of the oldest and most important publishing houses in Norway, engaged a researcher with special competence in dialectology and urban multiethnolectal speech styles to give a talk at the launch of their textbook Norsk for yrkesfag ('Norwegian for vocational studies') (Gitmark et al. 2013). In addition, they published a magazine with the title Språk og Strid ('Language and Struggle') with Danny Maroc, who is also featured in the textbook, on the cover. In the magazine there is an interview over two full-pages with Danny where the 
lyrics of his rap Norsk 2 ('Norwegian2') is included and discussed, like in the textbook (see section 2.2). In the interview Danny says that he had a wish to explain how multiethnolectal Norwegian, or 'Norsk 2', emerged and why. Furthermore he says that this speech style ought to be seen on par with dialects and sociolects and to be acknowledged like them, because, as he says: "we are also a part of Norway" (Aschehoug Undervisning 2014, p. 22).

Also the publishing house responsible for Intertekst, Fagbokforlaget, was eager to include a researcher with special competence in urban multietholectal speech styles in their book launch. In addition, they promoted the above-mentioned young debutant Maria Navarro Skaranger and her novel Alle utlendinger har lukka gardiner ('All foreigners have closed curtains') in their book launch. Even though the language rendered in her novel-according to Skaranger-is not meant to reflect the actual speech of the Eastern Oslo suburb she describes, it is promoted by the publishing house and referred to by reviewers as "Kebab Norwegian". The relative novelty and cool marginality associated with the speech style is clearly seen as something Fagbokforlaget may capitalize on in promoting and selling their textbooks Intertekst 1 and 3.

As we have seen, a broad meaning potential is associated with Kebab Norwegian, and this potential is exploited as commodity both in mainstream (theatre, literature, textbooks) and more oppositional (rap lyrics) cultural expressions. This is not unexpected, since an awareness of the intrinsic value of linguistic diversity has deep roots among Norwegians, and is, as we have seen, reflected in the school curriculum. The difference between the Norwegian and Danish Hip Hop scene mentioned earlier is interesting, and calls for further investigations into how the shaping and emergence of multiethnolectal styles relate to the global Hip Hop community. 


\subsection{Historical curricular parallels - claiming one's place}

If we consider the multiethnolectal speech style a new member of the Norwegian dialect flora, what will be its fate? As mentioned in the introduction, the Norwegian Parliament decided in 1878 that no particular spoken standard should be taught in elementary and secondary schools; the recommended language of instruction is (an adaption towards) the children's local dialects, the government proclaimed. This principle is still valid today, and there is (in principle) no tradition of correcting pupils' dialects. The principle of not correcting children's dialects seems, however, to be resticted to traditional dialects and not to changes in progress. Teachers are in fact still expected by many parents to "correct" children's innovative pronunciations associated with changes in progress. One recent example of this is the merger between the dorso-palatal fricative /ç/ and the post-alveolar fricative / $/$, both realized as $/ \int /$ by the younger generations, especially in urban areas. This is an example of an innovation appearing independently in different urban dialects. This is interestingly enough also an innovation and change which seems to escalate in multiethnic youth groups (Opsahl \& Røyneland, 2009, p. 107). Until very recently adolescents reported that they knew and were able to produce the distinction, but said that they did not want to (see Dalbakken, 1997). Apparently, the merger had come to function as a group identity marker among adolescents. Whereas the merger long has been associated with adolescent culture, sloppiness, childishness, and so on, using / $/ \mathrm{J}$ instead of /ç/ now seems to be fully accepted as the new norm in many adolescent environments. Though initially stigmatized, and subject to greater pressure toward norm maintenance than most contact-induced changes associated with dialect levelling (see Røyneland, 2009), we are facing a change in attitudes and a loss of potential meaning associated with the innovation, i.e. it no longer functions as a group identity marker. This developmental pattern shows how the relative indexical value of linguistic features may change relatively fast, and may perhaps serve as an indication to the likely fate of some of the 
linguistic characteristics associated with a multiethnolectal speech style. Although it has been subject to massive overt negative stigma, it may in time be accepted as legitimate in certain markets. Such a loss/transformation of meaning potential might in turn both reflect and enhance the didactic implications of including these features in a textbook understanding of the modern Norwegian dialect landscape. This, however, depends among other things on how the transformation of meaning potential — or more precisely the enregisterment processesinitialized by the multiethnolectal Hip Hop groups are transformed in future educational settings.

\subsection{Pure or not too pure}

An important question - or rather an important dilemma - is, evidently, the question of the relationship between the recommended language of instruction enshrined in the 1878 policy and the style emerging among youth in urban, multiethnic communities in Oslo. As we have seen, this speech style was - and to some extent still is - met with negative attitudes. There are traces in the history of spoken Norwegian which may account for this evaluation as well: Dialects in Norway are very often evaluated according to an ideal of purity.

Purism is the manifestation of a desire on the part of a speech community (or some section of it) to preserve a language form, or rid it of, putative foreign elements or other elements held to be undesirable (including those originating in dialects, sociolects and styles of the same language) (Thomas 1991, p. 12).

Attitudes toward mixed or leveled ways of speaking are not particularly favorable, and are often regarded both by the users of mixed varieties themselves and by others as "bad" or “poor'” ways of speaking (Røyneland, 2009; Mæhlum, 2011). This has to do with a view of 
language as something that should be kept pure, clean, and unspoiled. Mixing standard variants into the local dialect has traditionally been considered inauthentic and held in contempt (Blommaert \& Verschueren, 1998).

Assuming that a language ought to have a distinct territory and nation (or ethnic group of race) associated with it, scholars interpreted other kinds of language distributions as “mixtures", departures from some original linguistic and territorial purity (Irvine \& Gal 2000, p. 53)

This pattern is of course not unique to a Norwegian context. Androutsopoulos (2010, p. 184) shows how language ideologies surrounding dialects, contact varieties or non-standard speech: "generally provide social actors with resources for the discursive construction of social and cultural identities, and are important tools in excluding, stigmatizing or 'othering' individuals and groups." Despite this long-lasting and influential dogma of homogeneity, mixed or leveled ways of speaking seem nevertheless to be included in a less puristic and normatively more flexible spoken language ideology.

\subsection{Language struggle continued}

We have claimed that there are some interesting parallels between the formation and destiny of multiethnolectal speech styles and the past Norwegian language development and history, which in turn may have didactic implications. As we have already argued, Hip Hop plays a decisive role in the creation and formation of multiethnolectal speech styles. Hip Hop's oppositional symbolism is an important resource, as users aim to challenge hegemonic language ideologies. 
Cutler and Røyneland (2015) argue that the non-standard, multiethnolectal and heteroglossic language practices associated with Hip Hop function as a means for youth to differentiate themselves from others and express pride in their identity, and resist/transform traditional social and ethnic categories in the face of dominant ideologies. This is not new to Norway, but it is reminiscent of the linguistic identity struggles of the $19^{\text {th }}$ century and discussions of what constitutes the concept of (being) "Norwegian".

Svendsen and Marzo (2015) show how the aforementioned rapper Danny Maroc compares himself and his linguistic practices explicitly to the leading Norwegian language pioneers and national romantic poets of the 19th century who sought linguistic recognition of Norwegian as a distinct variety through so-called lexical enrichment. The rapper claims acceptance for the way he speaks, and argues that he is "updating the Norwegian language" since "we are now in a new era with many minority youth", and "that foreign words are natural". Svendsen and Marzo show how he actively projects 'multietnolect' in his rap lyrics, equivalent to what everybody else in Norway 'have', i.e. a dialect (Svendsen \& Marzo, 2015, p. 80).

The prestigous character and potential value associated with dialect variation is adressed through Danny's and other rappers' linguistic and artistic practices. The rappers seem to have both ideological and didactic intentions in their lyrics. By naming, demonstrating and claiming a place - both in the sense of geographical rooting and social recognition - they clearly take part in in the enregisterment and acknowledgement of these speech practices (Agha, 2005; Cutler \& Røyneland 2015; Silverstein 2003). One may say that the deep connections between language and belonging to a place is one of the most conspicuous cohesive elements in the rap lyrics, as well as in the use of the speech style in question. This 
observation coincides with what Androutsopoulos and Scholz (2003, p. 10) mention as the 'localizing' group of speech act patterns associated with text cultural norms of rap. The linguistic practices of these performers are in many ways supporting the high school textbooks authors in their choice of including not only multiethnolectal speech styles in their dialect chapters, but also their choice of framing their descriptions of linguistic diversity with Hip Hop elements. These insights correspond well to one of the overarching themes of this Special Issue, namely authenticity. The notion of authenticity shaped both in Hip Hop communities and in Hip Hop based educational experiences has its parallel in the formation and shaping of a new spoken variety. A multiethnolectal speech style makes place-in much the same way as dialects do. Geographical rooting and social orientation are obtained by young people, and at the same time the Norwegian language ideologies are re-shaped and "updated" to the current globalised times.

\section{Concluding remarks}

The link between Hip Hop and place making is strong and has the ability to challenge existing conseptions of language and society. We have shown how Hip Hop artists contribute to a remapping of the Norwegian dialect landscape. Three possible positions regarding the question of dialectal oritentation are demonstrated in our study. The first is the positive inclusion of multiethnolectal speech styles in the dialect flora of Norway, a position expressed by the majority of the high school textbooks we have examined, in rap lyrics and in (parts of) the urban communities in Norway. The reasoning behind this position may be found through an acknowledgement and juxtaposition of historical parallells with other language struggles and dialect levelling processes. What we see is a classical "change from below"-situation, where innovative patterns are re-evaluated over time. The second position is a recognition of new linguistic practices, but one in which they are framed as something other than or different 
from a dialect. This position is shared by some of the textbooks, by authors like Skaranger, and by some Hip Hop performers. This position may be grounded in an aestheic perspective: The novel, the lyrics, the performances such as Romeo and Juliet in rap, are different from everyday linguistic practices. Interestingly, these performances and aesthetic artifacts are nontheless often perceived by the general public as mirroring linguistic reality. The third position is found in media discourse and among conservative voices: a total depreciation based on strong purist and standard ideologies aimed at excluding and 'othering' (Androutsopoulos, 2010, p. 184) certain individuals and groups from the dialect landscape. But as we have seen, there are examples of how both certain varieties and certain innovative patterns have been met with a change of attitudes in the course of a short time-span. By letting rap lyrics from multicultural youth groups into the classroom one may illustrate several cultural and linguistic developmental processes which have been — and are- highlighted in the curriculum, in addition to the more traditional concept of bridging the gap between formal and informal learning contexts. The question remains, however, whether the possibilities made available in the textbooks actually are transformed into pedagogical practices in the classrooms. Our analysis shows that there is nothing speaking against an inclusion of a multiethnolectal speech style — framed by elements from Hip Hop culture — in the Norwegian curriculum. Rather the opposite is the case: Recognition of rap is a vital part of a deeper understanding of how reality rhymes.

\section{Acknowledgements}

We would like to thank the anonymous reviewers and the editors for their valuable comments to the first draft of this paper. This work is partly supported by the Research Council of Norway through its Centers of Excellence funding scheme, project number 223265. 


\section{References}

Aarsæther, F. (2010). The Use of Multiethnic Youth Language in Oslo. In P. Quist, \& B. A. Svendsen (Eds.), Multilingual Urban Scandinavia. New Linguistic Practices (pp. 111127). Bristol: Multilingual Matters.

Agha, A. (2005). Voice, footing, enregisterment. Journal of Linguistic Anthropology, 15(1), $38-59$.

Alim, S. (2009). Translocal style communities: Hip hop youth as cultural theorists of style, language, and globalization. Pragmatics, 19(1), 103-128.

Andresen et al. (2014). Signatur. [Signature] Norsk Vg2. Bergen: Fagbokforlaget.

Andresen et al. (2013). Signatur. [Signature] Norsk Vg3. Bergen: Fagbokforlaget.

Androutsopoulos, J. (2010). Ideologizing ethnolectal German. In S. Johnson \& T. Milani (Eds.), Language Ideologies and Media Discourse: Texts, Practices and Politics (pp. 182-202). New York: Continuum.

Androutsopoulos, J. (2009). Language and the three spheres of hip-hop discourse. In A. Ibrahim, S. Alim \& A. Pennycook (Eds.), Global Linguistic Flows: Hip Hop Cultures, Identities, and the Politics of Language (pp. 43-63). Mahwah, New Jersey: Lawrence Erlbaum.

Androutsopoulos, J., \& Scholz, A. (2003). "Spaghetti funk": Appropriations of hip-hop culture and rap music in Europe. Popular Music and Society, 26(4), 489-505.

Aschehoug Undervisning (2014). NORSKmagasinet. Språk og strid. [The NORWEGIANmagazine. Language and struggle] Oslo: Aschehoug.

Auer, P. (ed.) (2007). Style and Social Identities. Alternative Approaches to Linguistic Heterogeneity. Berlin, New York: Mouton de Gruyter. 
Blommaert, J. \& Verschueren, J. (1998). The role of language in European nationalist ideologies. In B. Schieffelin, K. Woolard, \& P. Kroskrity (Eds.), Language ideologies: Practice and theory (pp.189-210). New York: Oxford University Press.

Bourdieu, P. (1977). The economics of linguistic exchanges. Social Science Information, 16, $645-665$.

Bourdieu, P. (1992). Language and Symbolic Power. Cambridge: Polity Press.

Brunstad, E., Røyneland, U., \& Opsahl, T. (2010). Hip-hop, ethnicity and linguistic practice in rural and urban Norway. In M. Terkourafi (Ed.), The Languages of Global Hip-hop (pp. 223-256). London: Continuum.

Chambers, J., \& Trudgill, P. (1980). Dialectology. Cambridge: Cambridge University Press.

Clyne, M. (2000). Lingua franca and ethnolects in Europe and beyond. Sociolinguistica, $14,83-89$.

Cutler, C., \& Røyneland, U. (2015). "Where the fuck am I from?" - Hip-Hop youth and the (re)negotiation of language and identity in Norway and the US. In J. Nortier ,\& B. A. Svendsen (Eds.), Language, Youth and Identity in the 21st Century. Linguistic Practices across Urban Spaces (pp. 139-163). Cambridge: Cambridge University Press.

Dahl, T. G. et al (2013). Grip teksten. [Grab the text] Norsk Vg1. Oslo: Aschehoug.

Dahl, T. G. et al (2015). Grip teksten. [Grab the text] Norsk Vg3. Oslo: Aschehoug.

Dalbakken, L. O. (1997). Den “sjedelige” kj-lyden. Sj-uttale av kj-lyden - slurv eller språkending? [The "boring" kj-sound. Sj-pronunciation of the kj-sound - sloppiness or language change?] Språklig samling, 1, 5-10.

Duchêne, A., \& Heller, M. (eds.) (2012). Language in Late Capitalism: Pride and Profit. New York: Routledge.

Eide, O. et al. (2015). Intertekst. [Inter text] Norsk Vg3. Bergen: Fagbokforlaget. 
Ekberg, L., Opsahl, T., \& Wiese, H. (2015). Functional Gains: A Crosslinguistic Case Study on Three Particles in Swedish, Norwegian and German. In J. Nortier \& B. A. Svendsen (Eds.), Language, Youth and Identity in the 21st Century. Linguistic Practices across Urban Spaces (pp. 93-115). Cambridge: Cambridge University Press.

Eckert, P. (2001). Style and social meaning. In P. Eckert \& J. R. Rickford (Eds.), Style and Sociolinguistic Variation (pp. 119-128). Cambridge: Cambridge University Press.

Eckert, P. (2008). Variation and the indexical field. Journal of Sociolinguistics, 12(4), 453-476.

Furumo, M. R. et al. (2015). Norsk for påbygging. [Norwegian for supplementary program.] Oslo: Aschehoug.

Garthus Kvåle, K. M. et al. (2013). Intertekst. [Inter text] Norsk Vg1. Bergen: Fagbokforlaget. Gedde-Dahl, T. et al. (2013). Tett på. [Close up] Norsk Vg1. Oslo: Gyldendal.

Gedde-Dahl, T. et al. (2016). Tett på. [Close up] Norsk Vg3. Oslo: Gyldendal.

Gitmark, C. et al. (2014). Norsk for yrkesfag. [Norwegian for vocational studies] Oslo: Aschehoug.

Grepstad, O. (2015). Språkfakta. Ei forteljing om språk $i$ Noreg og verda gjennom 850 tabellar. [Language facts. A story about language in Norway and the world through 850 tables] Volda: Nynorsk kultursentrum.

Haugen, E. (1966). Language Conflict and Language Planning: The Case of Modern Norwegian. Cambridge MA: Harvard University Press.

Heller, M. (2010). The Commodification of Language. Annual Review of Anthropology, 39, $101-114$.

Hårstad, S., \& Opsahl, T. (2013). Språk i byen. Utviklingslinjer $i$ urbane språkmiljøer $i$ Norge. [Language in the city. Developments in urban linguistic environments in Norway] Bergen: Fagbokforlaget. 
Ims, I. I. (2014). “Alle snakker norsk”. Språkideologi og språklig differensiering i mediene. ["Everyone speaks Norwegian." Language ideology and linguistic differentiation in the media] NOA - Norsk som andrespråk [Norwegian as a second language], 30(1), 5-40.

Ims, I. I. (2013). Språklig registerdanning og verditilskriving. Betegnelser på nye måter å snakke norsk på i Oslo. [Linguistic enregisterment and value ascription. Designations of new ways of speaking Norwegian in Oslo] NOA - Norsk som andrespråk, [Norwegian as a second language],29(2), 37-71.

Irvine, J. T., \& Gal, S. (2000). Language ideology and linguistic differentiation. In P.V. Kroskrity (Ed.), Regimes of Language: Ideologies, Polities, Identities (pp. 35-83). Santa Fe, NM: School of American Research.

Jahr, E. H. (2003). Norwegian. In A. Deumert, \& W. Vandenbussche (Eds.), Germanic Standardizations: Past to Present [Impact: Studies in Language and Society 18], (pp. 331-355). Amsterdam: John Benjamins.

Jahr, E. H., \& Mæhlum, B. (Eds.) (2009). Tema: Standardtalemål. [Standard Language. Norsk lingvistisk tidsskrift [Journal of Norwegian Linguistics] 27(1).

Kulbrandstad; L.-A. (2004). "Kebabnorsk", "perkerdansk" og "gebrokken" - ord om innvandreres måte å snakke majoritetsspråket på. ["Kebab-Norwegian", "PerkerDanish" and "broken language" - labels for immigrants' way to speak the majority language.] In H. Sandøy, E. Brunstad, J. E. Hagen \& K. Tenfjord (Eds.), Den fleirspråklege utfordringa [The multilingual challenge] (pp. 114-135). Oslo: Novus.

Language Counsil of Norway (2016). Minoritetsspråk ('Minority Languages') http://www.sprakradet.no/Spraka-vare/Minoritetssprak/ Accessed 28.04.16.

Mæhlum, B., \& Røyneland, U. (2009). Dialektparadiset Norge - en sannhet med modifikasjoner [The Norwegian dialect paradise - a qualified truth.] In I. S. Sletten; A. 
Gudiksen (eds.), I Mund og Bog. [In mouth and Book]. (pp. 219-231). Afdeling for dialektforskning, Nordisk forskningsinstitut, Københavns universitet.

Mæhlum, B. (2011). Det “ureine” språket: forsøk på en kultursemiotisk og vitenskapsteoretisk analyse. [The "impure" language: a culture semiotic and epistemological analysis] Maal og Minne, 1, 1-31.

Nortier J., \& Svendsen, B. A. (Eds.) (2015). Language, Youth and Identity in the 21st Century. Linguistic Practices across Urban Spaces. Cambridge: Cambridge University Press.

NRK/Norstat (2014). Språk. NNA36491. [Language]. Survey on language attitudes N=1000, Nov. 2014. Unpublished. Oslo: NRK.

Opsahl, T. (2009). "Egentlig alle kan bidra!" - en samling sosiolingvistiske studier av strukturelle trekk ved norsk i multietniske ungdomsmiljøer i Oslo. ["Actually, anyone can contribute!" - A collection of sociolinguistic studies of structural features of Norwegian in multiethnic youth communities in Oslo.] Ph.d.-thesis. University of Oslo.

Opsahl, T., \& Røyneland, U. (2009). Osloungdom - født på solsiden eller i skyggen av standardtalemålet? [Oslo youth - born on the sunny side of the street or in the shadow of the standard language.] Norsk lingvistisk tidsskrift [Journal of Norwegian Linguistics.] 27(1), 95-120.

Oslo Municipality (2016). http://statistikkbanken.oslo.kommune.no/webview/ Accessed 25.04.16.

Pennycook, A. (2007). Global Englishes and Transcultural Flows. London: Routledge.

Pennycook, A., \& Otsuji, E. (2015). Metrolingualism. Language in the city. New York: Routledge.

Quist, P. (2005). Stilistiske Praksisser i Storbyens Heterogene Skole. En etnografisk og sociolingvistisk undersøgelse af sproglig variation. [Stylistic practices in the big city's 
heterogenous school.], Ph.d.-thesis, Københavns universitet: Nordisk Forskiningsinstitut, afd. for dialektforskning.

Quist, P. (2008). Sociolinguistic approaches to multiethnolect: Language variety and stylistic practice. The International Journal of Bilingualism12 (1 \& 2), 43- 61.

Quist, P., \& Svendsen, B. A. (Eds.) (2010). MultiLingual Urban Scandinavia. New Linguistic Practices. Bristol: Multilingual Matters.

Rotevatn, A. G. (2014). Språk i spagaten. Facebook-språket. Om normert språk og dialekt blant vestlandselevar [Language doing the splits. Facebook language. On standard language and dialect among pupils in Western Norway.] MA-thesis. Volda University College.

Røskeland, M. et al. (2013). Panorama. Vg1. Oslo: Gyldendal.

Røskeland, M. et al. (2015). Panorama. Vg3. Oslo: Gyldendal.

Røyneland, U. (2009). Dialects in Norway: catching up with the rest of Europe? International Journal of the Sociology of Language.,196/197, 7-31.

Røyneland, U. (2010). Vertical convergence of linguistic varieties in a language space. In P. Auer \& J. E. Schmidt (Eds.), Language and space - an International Handbook of Linguistic Variation. Volume 1: Theories and Methods (pp. 259-274). Berlin, New York: Mouton de Gruyter.

Røyneland, U. (2013). "The voice from below": Norwegian language reforms in the 21st century. In T. Lohndal (Ed.), In Search of Universal Grammar: From Old Norse to Zoque, (pp. 53-76). Amsterdam: John Benjamins.

Røyneland, U. (in press). Hva skal til for å høres ut som du hører til? Forestillinger om dialektale identiteter i det senmoderne Norge. [What should you sound like to sound like you belong? Notions of dialectal identities in late modern Norway]. Nordica Helsingiensia. 
Silverstein, M. (2003). Indexical order and the dialectics of sociolinguistic life. Language and Communication, 23,193-229.

Skaranger, M. N. (2015). Alle utlendinger har lukka gardiner. [All foreginers have closed curtains.] Oslo: Oktober.

Sollid, H. (2009). Utforsking av nordnorske etnolekter i faghistorisk lys. [Exploring northern Norwegian ethnolects in light of their academic history.] Maal og Minne, 101 (2), $147-$ 169

Sollid, H. (2014). Hierarchical Dialect Encounters in Norway. Acta Borealia, 31 (2), 111130.

Statistics Norway (2016). http://www.ssb.no/innvbef/ Accessed 25.04.16

Stjernholm, K. (2013). Stedet velger ikke lenger deg, du velger et sted. Tre artikler om språk $i$ Oslo. [The place no longer chooses you. You choose a place. Three articles about language in Oslo]. PhD-thesis, Faculty of Humanities, University of Oslo.

Stæhr, A., \& Madsen, L. M. (2014). Standard language in urban rap - Social media, linguistic practice and ethnographic context. Tilburg Papers in Cultural Studies,94,Published online: https://www.tilburguniversity.edu/upload/1210cac3-2abf-42d7-84b5f545916b4d15 TPCS 94_Staehr-Madsen.pdf Accessed 22.12.15.

Svendsen, B. A. (2014). Kebabnorskdebatten. En språkideologisk forhandling om sosial identitet. [The debate on Kebab-Norwegian. A language ideological negotiation on social identity.] Tidsskrift for ungdomsforskning [Journal on youth research.], 2014 (1), $33-62$.

Svendsen, B. A., \& Røyneland, U. (2008). Multiethnolectal facts and functions in Oslo, Norway. International Journal of Bilingualism, 12 (1 \& 2), 63-83. 
Svendsen, B. A., \& Marzo, S. (2015). A 'new' speech style is born. The omnipresence of structure and agency in the life of semiotic registers in heterogenous urban spaces. European Journal of Applied Linguistics, 3 (1), 47-85.

Terkourafi, M. (Ed.) (2010). The Languages of Global Hip-hop. London: Continuum.

Thingnes, J. S. (2015). Skriftmangfald på norsk: språkforvaltning, normbrot og språkhaldningar. [Diversity in written Norwegian: Language management, violation of norms and language attitudes.] Unpublished MA-thesis, University of Oslo.

Thomas, G. (1991). Linguistic Purism. London, New York: Longman.

Trudgill, P. (2002). Sociolinguistic variation and change. Edinburgh: Edinburgh University Press.

Udir (2015). National Curricula. http://www.udir.no/k106/NOR105/Kompetansemaal/?arst $=1858830315 \& \mathrm{kmsn}=-2089340600$ Accessed 22.12 .15 